and determines it. This statement, in just so far as it is true, contains a serious argument in favor of the contemplative life, and, since mysticism is a function of asceticism, is the best apology for ascetic mysticism.

BRYN MAWR COTLEGE.

Grace Fernald.

\title{
HISTORY OF PHILOSOPHY.
}

La Philosophie en Amérique depuis les origines jusqu'à nos jours (1607-1900). Essai historique. L. van Becelaere, O. P. Introduction by Josiah Royce. New York, Eclectic Publishing Company, 1904. Pp. xvii + iso.

Out of the articles appearing in the Revue Thomiste in 1902-O3 there grew this historical monograph on a subject which has hitherto been treated in brief resumes only. In an effort to be historical rather than critical, the author gives an excellent, though somewhat incomplete, exposition of the philosophical work that has been done 'in America' in the eight chapters which the book comprises. Chapter I. treats of 'The American Spirit and Speculative Thought'; II., 'The Colonial Period (1607-1 765)'; III., 'Scotch Influence'; IV., - Influence of German Philosophy (transcendentalism in New England)'; V., 'Contemporary Schools-Idealists'; VI., "The Philosophy of Evolution'; VII., 'Psychology'; VIII., 'The Present Time.' The epilogue looks forward to what philosophy may become amongst us, and in an appendix mention is made of the attitude and achievements characteristic of the thought which is maintained by the thinkers in the Roman Catholic church.

Since Porter's brief but scholarly review of 'Philosophy in America' which appeared thirty years ago, as a part of his contribution to Morris's translation of Ueberweg's History of Philosophy, there has not been a more extensive attempt to bring together in proper balance and with adequate historical perspective the facts which go to characterize what some of us are more and more adventuresomely calling 'American' philosophy. Perhaps the most interesting feature of this book is the fact that it was written by one whose theological training and views are those least allied to philosophy during its entire modern development, and consequently showing least influence in the determinative agencies at work in shaping American thinking. The author's scholarship and the warmth of his appreciation of philosophical developments are so unusual that any student of the subject can be both instructed and entertained by this account. 
And to those jingoists who insist that there is such a thing as 'the American mind' there can now be administered the proper tonic which is afforded by this opportunity to see ourselves as others see us.

In explaining the relative absence of speculative thought in America, the author looks to the susceptibility to outside influences and the ready adaptation of realism to practical life as the tendencies which have prevailed in 'the great machine shop' which American activity has been so far. In the hurly-burly of three practical centuries, the philosophical voice could not be heard. While properly assuring us that there is no such thing as 'an American philosophy' the author daringly looks to the undated future when America will be the modern Greece. He contends that America is like ancient Greece; and, in prophesying our future intellectual developments, he derives comfort for his arguments from the similarity of geographical position, climate, wealth, practical ability and mental qualities between the two nationalities (pp. I 2-I 3 ).

The antecedents of philosophy in America, which were chiefly religious in tone and individual in development during the first century, are said to be Calvinistic scholasticism and the philosophical spirit borrowed from the contemporary Lockean doctrine of ideas. These two elements were united in Jonathan Edwards, with whom was born in America not plailosophy, nor a philosophy, but philosophical speculation. His influence was not to indoctrinate, but to make men think.

The range of Scotch influence is traced during two periods, first its reign (1800-1860), and second its decline (1860-1900). The treatment of men and writings is full, but goes a little too far, perhaps, when dealing with contemporaries of to-day in classing most ardent theists and intuitional moralists as direct descendants of Scottish realism.

The influence of German plilosophy is adequately told in the full and interesting account of the appearance and development of New England transcendentalism and of the events associated with Concord, our 'transcendental Mecca.' In the academic institutions during this period Scottish thought was chiefly dominate, and, of course, had the widest range of influence.

In dealing with current tendencies, it is noteworthy that the author finds idealism to be the undeniably dominant type of speculative thought, particularly in the domain of metaphysics, and probably in ethics (p. 105). When stating, however, that Lotze, Green and Hegel are the important authorities to American thinkers in this 
movement, he hardly does historic justice to the present day significance of renewed interest in the neo-Kantian movement.

Realism and Saxonism (if one may mix logic and blood!), mingled in the American type of mind, lead it to an unusual interest in positive science and in the evolutionary generalization which has been derived from it. The treatment of the philosophy of evolution is grouped about its defenders and its adversaries, and is fairly complete. Just why anthropology, religious philosopluy and social science as American subjects are grouped in the same chapter with evolution, is not made plain. This mode of treatment makes it necessary for the author to repeat his treatment of men, and shows the limitations produced by the tendency to cross the historical and the logical developments. Psychology is regarded as a science and not as a branch of philosophy. The historical review is interested chiefly in its experimental developments, from which the author is not inclined to anticipate any great intellectual reformations. He falls back upon Wundt in support of his position.

In reviewing the present tendencies, the account includes a description of the varied machinery that has been produced to maintain and to extend philosophical thinking and teaching among us, such as the periodical press, the higher institutions with their professorial chairs, text-book material, and the several associations recently organized. These agencies give the author an optimistic view of the future, particularly when he is noting the social and political fusion which is being wrought among us. Americanism thus means to him a unified people who have a soul, an inner unity, which needs a rational basis, and possesses a moral and intellectual sanity guaranteeing national existence and duration.

UNTVRRSITY OF ALABAMA.

Edward FrankLin Buchner.

\section{EPISTEMOLOGY.}

Scepticism. A. K. Rogers. Philosophical Review, r904, XIII., $627-64 \mathrm{r}$.

By scepticism the author means 'that somewhat unsystematic attitude whose ground is to be found primarily in an appeal to the fact of error, and a challenge to point out the marks by which we might recognize truth if we once were to stumble on it.' In the beginning the article sets forth the sceptic's attitude, his questions, and his complaints. "How can one," asks the sceptic, "be any more assured of the validity of to-day's conceptions than he was of yester- 